\title{
Teaching Speaking: an Exploratory Study in Two Academic Contexts
}

\author{
Rosa Alonso Alonso \\ University of Vigo
}

Received: 15 May 2013 / Accepted: 31 July 2013

ISSN: $1697-7467$

\begin{abstract}
This paper analyses the teaching of speaking in secondary education (SE) institutions and state language schools (EOI) in Spain. Eighty teachers participated in the study. The research instrument was a questionnaire which focused on the time devoted to the teaching and practising of spoken English, the assessment of speaking, the type of activities they used and frequency of their use. A Wald-type test was used in the data analysis. Findings indicate that EOI teachers devote more time to the teaching and practice of speaking, focus more on pronunciation and interaction in the assessment of speaking, and prefer lesscontrolled tasks.
\end{abstract}

Keywords: teaching, speaking, secondary education, schools of languages, skill

\section{Enseñar comunicación oral: un estudio exploratorio en dos contextos académicos}

RESUMEN: Este artículo analiza la enseñanza de la destreza oral en instituciones de educación secundaria (SE) y escuelas de idiomas (EOI) en España. Ochenta profesores participaron en el estudio. El instrumento de investigación fue un cuestionario que se centra en el tiempo dedicado a la enseñanza y práctica del inglés hablado, su evaluación de esta destreza, el tipo de actividades utilizadas y su frecuencia de uso. Se utilizó un test tipo Wald para el análisis de los datos. Los resultados indican que los profesores de EOIs dedican más tiempo a la enseñanza práctica de la lengua oral, se ocupan más de la pronunciación y la interacción con hablantes nativos y prefieren actividades menos controladas.

Palabras clave: enseñanza, destreza de producción oral, educación secundaria, escuelas de idiomas, destreza

\section{INTRODUCTION}

English is the most widely spoken foreign language in Europe. Nevertheless, students in Spain are generally not able to speak English fluently by the end of compulsory secondary education (henceforth SE). Indeed, according to a Eurobarometre survey (2005), this country has one of the lowest levels of proficiency in English in Western Europe. The concern to improve students' communicative skills in English is reflected in various pieces of legislation covering the Spanish educational system (General Organic Law of the Educational System, Organic Law of the Education of Quality, Organic Law of Education). English as a Second Language is taught as a compulsory subject in Spanish SE. Foreign languages, including English, can also be learned in state language schools (henceforth EOI) to be found throughout the country in large and middle-size cities. They teach elementary, intermediate 
and advanced levels across a total of six grades. On passing an exam at the end of the six grades the students obtain a certificate of their proficiency in the language studied. EOIs are governed by a national legal framework (Royal Decrees 967/1988, 1523/1989, 47/1992, 944/2003, 423/2005) Since EOIs specialize in second language learning, they are expected to devote greater attention to the teaching of speaking than SE schools. However, to the best of our knowledge, no study has thus far compared the teaching of this skill in the two kinds of institutions. The purpose of this paper, then, is to fill that gap through ascertaining which type of institution typically pays more attention to the teaching of speaking skills; the study has been carried out in Galicia, a region of north-western Spain. Three key issues are addressed: (a) the time teachers devote to teaching speaking and to the practice of speaking activities, (b) the attention they pay to the assessment of the different components of speaking (accuracy, fluency, pronunciation) and (c) the type of speaking tasks carried out. Sections 1 and 2 below deal with the theoretical background of the study, including a brief historical overview of the topic, the speaking skill in language teaching, and relevant studies conducted in Galicia. Following sections report on the current empirical study, which was conducted with eighty informants comprising forty secondary education teachers and forty EOI teachers. Then the findings are discussed. Finally, the questionnaire that was used in the research is included as an appendix.

\section{Historical Overview on the Teaching of Speaking}

Although the practice of speaking in the classroom is a key element in the development of the second language, oral skills have not always been central in second language teaching methodologies. The grammar-translation method traditionally focused on reading texts and sentences, translating them from the L1 to the L2 and viceversa. This type of practice usually involved specific grammatical problems and the practice of speaking tended to involve the comparison of the L1 and the L2 . This method focused mainly on grammatical rules, syntactic structures and the memorisation of vocabulary, and hence speaking skills were not priority. Moving on, the Reform Movement (Howatt, 1984) considered that resorting to comparisons with the L1 was not the best way to achieve fluency in L2 use. Instead, speech was seen as a key element in the teaching of language. Speech also provides a channel for language learning, as Bygate (2009) notes in that it occurs in real time between interlocutors and is an appropriate vehicle for the use of imitation and correction techniques which enable the automation of language processing. Speech as a medium for learning therefore came to be used in a variety of different approaches which embraced the scope it offered for immediacy, correction and repetition. The Direct Method and the Audiolingual Method, for example, focused on repetition and instant correction as a way of learning the L2. The former takes oral communication as fundamental and pronunciation is emphasized from the outset; as opposed to the grammar-translation method, the students' native language is not used in the classroom. The latter emphasizes language structures with vocabulary and grammar structures tending to be presented through dialogues which are learned by imitation and repetition. Communicative language teaching, in turn, followed a functional approach and favoured the pragmatic functions of speech (see for example Morrow and Johnson, 1979). Both Communicative Language Teaching and The Silent Way 
share a focus on personal communication, that is, on the personal aspect of speech and are thus oriented towards learners' individual learning processes and personal communication. In The Silent Way, for example, the personal aspect of speech can be seen in the focus on the use of language for self-expression and on developing independence from the teacher. Personal communication is also relevant in the Communicative Approach and indeed the focus of this method lies squarely on becoming communicatively competent so as to use the language appropriately in given communicative contexts. This approach takes the position that linguistic competence must develop along with the ability to convey intended meaning appropriately in different social contexts. Current interactionist and socio-cultural approaches also focus on the negotiation of meaning in face-to-face interaction. The same can be said of socio-constructionist approaches where speech is considered as the primary medium for the negotiation of meaning. As can be observed, speaking per se has not always been the main focus of interest in these different approaches but has often been seen as a means of developing teaching methodologies. In other words, teaching the speaking skill has frequently not been an objective in its own right. As Bygate (2009:4) says "speaking is often seen as how it can contribute to language acquisition in general."

\section{The Speaking Skill in Language Teaching}

Despite the relevance that speaking has in second language use, few recent studies have been devoted to the teaching of speaking, with the exception of Boxer and Cohen (2004), Bygate (2000), Bygate, Skehan and Swain (2001) and Ellis (2005). The term "speaking" can be defined in different ways, depending on whether the focus is on its form, in which case, it might include issues such as grammar or prosodic features or whether it is understood more broadly in its communicative function. The main feature which distinguishes spoken language, however, is its interactive nature and hence, conversation is often taken to be a synonymous with speaking skill.

In the field of teaching second languages, speaking is a demanding skill, as Brown (1994) has described with phenomena such as vowel reduction and elision making the production of good spoken language difficult. Lazaraton (2001) also considers that elements such as slang and idioms render speaking a difficult skill to acquire, not to mention stress, rhythm and intonation. A further difficulty, as Checa (2002) has pointed out, is that although the teacher may explain a rule in the L2, the learners will often not actually put it into practice to any great extent:

If you are a teacher resign yourself to the idea that language can be taught as a set of rules and examples which will turn into adequate performance when the moment comes, then you are refusing to take notice of the fact that language items take on particular values in context and that many students who are grammatically competent cannot use the L2 in real performance. (Checa, 2002:22).

Bygate (1987) believes speaking to be an undervalued skill. Given that humans have the ability to speak, the skill is taken for granted in a first language, whereas writing skills will always require some training, which leads to them being overvalued. Yet, speaking in a 
second language also requires specific training in that it is a different and more complicated process which requires coding a message on the part of the speaker and decoding it on the part of the listener. The qualities of spoken language also need to be considered in teaching this skill and can be divided into three main areas generally associated with performance: fluency, complexity and accuracy. In fact, complexity and accuracy are intimately related to the construct of fluency. This latter term is defined by Segalowitz (2003:384) as "an ability in the second language to produce or comprehend utterances smoothly, rapidly, and accurately". The rate of delivery is associated with the ability to produce linguistic structures and Bygate (2009) distinguishes here between speed and regularity, which refers to the quantity and organization of pausing. Skehan and Foster (2005) in turn, identify two key elements of fluency: breakdown fluency and repair fluency, the former referring to interruptions which focus on "creating addition at processing time" (Bygate, 2009:10) and the latter being those interruptions which happen when the speakers corrects "aspects of formulation and articulation" (Bygate, 2009:10). Teachers should pay attention to accuracy and fluency, and should understand fluency not only as the ability to link elements in speech but also as "natural language use" in Hedge's (1993) terms. As we can see, although the nature of speaking is interactive, this skill has not always been central to second language teaching methodology and it is also important that accuracy and fluency be taken into account as a means of promoting language use

\section{The Teaching of Speaking in Galicia}

The poor linguistic skills shown by Galician students led the regional government to create an official plan to improve the knowledge of foreign languages (Plan Galego de Potenciación das Linguas Estranxeiras, henceforth, PPLE) Indeed, concern over the learning of English had already led to Article 23/Decree 79 May 20th, 2010 on plurilingualism which stipulated that learning should be improved by promoting activities among teachers, students and teaching institutions (DOG 25-05-2010). The main objective of the PPLE is to improve the four skills so that high school students can communicate in the L2 as independent users at level B2 of the Common European Framework of Reference for Languages (henceforth CEFRL) (Council of Europe, 2001). However, little research has so far been conducted into the teaching of speaking or into its possible implications for the generally low level of language proficiency shown by the students. Two main types of studies have been carried out in Galicia regarding the teaching of this skill: projects funded by the Galician government and doctoral theses undertaken in Galician universities. Projects generally have a specific educational purpose, the most pertinent being Vez et al's (2002) which focuses on the poor communicative competence that Galician students show at the end of their compulsory education. Most studies about teaching and learning in Galicia take the students' perspective. Vez et al's study follows the same line of research; a total of 246 students took part in the study. On a scale of $0-25,51 \%$ of the students of English as a L2 did not achieve a level of 3 in speaking. Grammar and pronunciation constitute the most difficult areas for the students while fluency obtains better results. The second type arises from doctoral research. For example, the study by Palacios (1994) is based on his doctoral thesis and shows that students consider speaking to be their weakest skill. A more recent thesis by Sanz (2011) 
focuses on the regression of communicative competence in English as L2 in SE, more specifically on the regression shown by students after their summer vacation. Twenty-two students took part in this longitudinal study which lasted two academic years and which showed that although the results improved in the second semester of the academic year, the subjects did not achieve a better mean than before the summer holidays.

Studies carried out in Galicia, then, have focused mainly on the students' perspective and have not compared the teaching of English in the contexts of EOIs and SE institutions. In the following sections we will describe and discuss an empirical study of the teaching of speaking in these two academic contexts.

\section{The Study}

The present study compares and contrasts the teaching of speaking in state language schools and secondary education institutions with the purpose of discovering which of these two groups pays more attention to the teaching of the speaking skill. Since EOIs deal with second language learning while SE institutions focus on general cultural training, it is expected that EOI teachers will provide better training for students in speaking. However, as noted above, thus far, no study has been carried out to determine whether this is in fact the case. The present study, then, tries to fill that gap by answering the following questions:

1. Which group of teachers devotes more time in the classroom to both the teaching of spoken English and to speaking practice through activities?

2. In the assessment of speaking, which group of teachers pays more attention to pronunciation, accuracy, fluency, interaction with their peers or with non-native speakers and to interaction with native speakers?

3. Which group of teachers makes a greater use of controlled speaking activities? Which group prefers less controlled activities?

In order to look into these issues, the study compares and contrasts the way SE and EOI teachers deal with the speaking skill in terms of classroom management, the time they devote to the teaching and practice of this skill, together with the types of activities that are carried out and the assessment of speaking skills. In the following sections a description of the subjects participating in the study is provided. This is followed by the data collected and its analysis, plus a discussion of the findings.

\subsection{Participants}

The participants in this research are all in-service teachers from twelve secondary schools and two EOIs in Galicia, hence this study is limited to this north-western region of Spain. The subjects have not been selected at random, they have been selected from the SE schools and EOIs of southern Galicia. A total of eighty participants took part: forty SE teachers and forty EOI teachers. The ages of the informants range from 25 to 66 years with SE teachers ages between 28 and 66 and EOI teachers between 25 and 58. Most SE teachers are over fifty and have been teaching for more than twenty years, while EOI teachers are between 30 and 39 and have been teaching for a period of one to five years. 


\subsection{Materials and procedures}

The analysis of the role of the teacher in the teaching of speaking was based on a questionnaire about their personal background and classroom management. It contained items relating to (a) the time they devote to the teaching of English, that is, to teach this skill and explain the ways in which the students are taught how to carry out the tasks and to (b) the practice of speaking activities, which refers to the time devoted to the activities themselves, and to (c) how teachers assess the different aspects of speaking (pronunciation, accuracy, fluency and interaction both with native and non-native speakers) and (d) the type of activities used and whether these are controlled and/or less controlled as well as (e) the frequency of use of these in the classroom.

In order to test the validity of the questionnaire as a research instrument, and hence the reliability of the data to be obtained, the questionnaire was first piloted by ten teachers (five SE teachers and five EOI teachers). On receiving their suggestions, some items were eliminated and others introduced. The final questionnaire was then given to the head of each of the teaching centres who distributed it among the English teachers and the completed forms were handed back to the head. Data were classified and processed using Excel file and subsequently analysed statistically using a Wald-type test for comparing proportions.

\subsection{Results}

\subsubsection{Time devoted to the teaching of spoken English and to the practice of speaking activities}

Most EOI teachers report devoting more than thirty minutes out of every sixty-minute lesson to the teaching of spoken English while only 15\% of SE teachers claim to do so. A similar number of teachers from both groups report devoting twenty to thirty minutes to this skill. However it is clear that overall EOI teachers spend more time teaching speaking. When we apply a Wald-type test here, the EOI group shows a mean of 33.6 (standard deviation of 8.9), as opposed to a mean of 20 in the SE group (standard deviation of 10.2). The time devoted to the teaching of spoken English in every lesson is much higher in the EOI group with a p-value $<0.001$.

Similar results are observed in the time teachers report devoting to the practice of speaking, that is, to the speaking activities themselves. The EOI group reports practising speaking activities in the classroom to a much larger extent. There is a remarkable difference between the two groups in the period of time that covers thirty minutes of practice. The application of the t-test indicates a mean of 33.2 in the EOI group, (standard deviation 9.2) and 17.1 in the SE group (standard deviation 9.3). A significant difference can be observed between both groups with far greater practice of speaking activities seen in the EOI group than the SE group ( $\mathrm{p}$-value $<0.001)$.

\subsubsection{Assessment of the components of oral communication}

Teachers were asked about the elements they considered in the evaluation of their students' oral production. They were specifically asked to mention whether they assessed 
pronunciation, accuracy and fluency. Attention was also paid to whether teachers considered the recipients of the spoken message, that is, whether they evaluated students' ability to communicate in English with their peers and other non-native speakers (interaction with anyone) or whether students' production was assessed under the criterion of how a native speaker might receive the spoken message (interaction with native speakers). In the case of "interaction with native speakers", EOI teachers report paying attention to the idea of native speakers as potential recipients of the message $32.5 \%$ of the time, whereas this is only $7.5 \%$ in the case of SE teachers. A Wald-type test indicates a statistical significant difference between both groups here ( $p$-value $=0.002$ ). However, we might note that in neither group is sufficient importance given to this issue. There is also a considerable difference in the assessment of accuracy between the groups $(p$-value $=0.007)$ while differences are smaller in the assessment of fluency and pronunciation.

Table 1. Assessment of oral skills

\begin{tabular}{|lll|}
\hline ISSUE ASSESSED & EOI & SE \\
\hline Interaction with native speakers & 32.50 & 7.50 \\
\hline Interaction with anyone & 92.50 & 75 \\
\hline Fluency & 72.50 & 62.50 \\
\hline Accuracy & 35 & 12.50 \\
\hline Pronunciation & 70 & 47.50 \\
\hline
\end{tabular}

\subsubsection{Speaking activities: Types and frequency of use}

An analysis of the speaking activities that teachers use most often indicates that in the $\mathrm{SE}$ group controlled activities (question-answer sequences, information gap activities, describe and draw, describe and arrange, spot the difference and presentations) are favoured to a slight degree. Controlled activities refer to those tasks where learners are given the linguistic patterns they are going to use, which implies a higher degree of control on the part of the teacher, while in less-controlled tasks or fluency practice tasks students have to use vocabulary or formulaic expressions in arriving at a communicative, interactive outcome. Hence, students focus more on developing fluency, and the teacher has a less dominant role in less-controlled activities. EOI teachers favour the use of less-controlled speaking activities (story telling, discussions and debates, simulations and role-plays) far more than their SE counterparts. Besides, in the case of EOI teachers, there appears to be a correspondence between the type of speaking activity used the most and the oral characteristic assessed, with EOI teachers reporting the use of less controlled speaking activities and valuing both " interaction with anyone" and fluency, and since performance in dynamic tasks tends to improve with practice (Brown and Yule, 1983) students can be expected to benefit from these.

When teachers were specifically asked about the length of time they used controlled speaking activities more EOI teachers in fact reported using this type of activities than SE teachers. The application of a Wald-type test shows a significant statistical difference here 
$(p$-value $=0.003)$. The EOI group, then, makes significantly greater use of less controlled activities. These findings on the frequency of use of controlled and less-controlled activities indicate that whereas both groups use them often, considerable differences are found in the frequency of use of less-controlled speaking activities.

Table 2. Controlled speaking activities: Frequency of use

\begin{tabular}{|lll|}
\hline $\begin{array}{l}\text { CONTROLLED SPEAKING } \\
\text { ACTIVITIES }\end{array}$ & EOI & SE \\
\hline Always & 6.7 & 10.9 \\
\hline Very often & 17.6 & 23.6 \\
\hline Often & 39.9 & 36.9 \\
\hline Sometimes & 14.7 & 22.8 \\
\hline Very rarely & 21.1 & 5.8 \\
\hline
\end{tabular}

Table 3. Less controlled speaking activities. Frequency of use

\begin{tabular}{|lll|}
\hline $\begin{array}{l}\text { LESS CONTROLLED SPEAKING } \\
\text { ACTIVITIES }\end{array}$ & EOI & SE \\
\hline Always & 21.5 & 5 \\
\hline Very often & 41.4 & 18.7 \\
\hline Often & 23.6 & 45.1 \\
\hline Sometimes & 11 & 25.9 \\
\hline Very rarely & 2.4 & 5.3 \\
\hline
\end{tabular}

In table 2 it can be observed that in controlled speaking activities, question-answer sequences are used similarly by both groups. EOI teachers, though, prefer using presentations and this is statistically significant ( $\mathrm{p}$-value $=0.001$ ). In less-controlled speaking activities, a statistical significant difference is found between the two groups, the EOI making greater use of role-play, problem-solving and discussions and debates than the SE group (p-value $<0.001$ ) and simulations ( $\mathrm{p}$-value $=0.005)$. There is substantial evidence, then, that the EOI teachers use less controlled speaking activities to a much greater extent. 
Table 4. Types of controlled-speaking activities

\begin{tabular}{|lll|}
\hline TYPE OF ACTIVITY & EOI & SE \\
\hline Presentation & 82.5 & 50 \\
\hline Spot the difference & 40 & 37.5 \\
\hline Describe and arrange & 30 & 40 \\
\hline Describe and draw & 30 & 25 \\
\hline Information-gap & 62.5 & 52.5 \\
\hline Question-answer & 95 & 90 \\
\hline
\end{tabular}

The type of activities that SE teachers favour implies a higher control on the part of the teacher. Students' autonomy is not promoted and instead the students are provided with the linguistic patterns they should produce (cf. Argibay, 2008), with more focus consequently falling on motor-receptive skills. The importance that SE teachers attach to the knowledge and practice of grammar by means of controlled activities does not enable students to improve their vocabulary. On the other hand, table 5 illustrates the preference for less-controlled speaking activities by the EOI teachers.

Table 5. Types of less-controlled speaking activities

\begin{tabular}{|lll|}
\hline \multicolumn{1}{|c|}{ YPE OF ACTIVITY } & EOI & SE \\
\hline Role-plays & 95 & 62.5 \\
\hline Simulations & 70 & 42.5 \\
\hline Problem-solving & 55 & 17.5 \\
\hline Discussions and debates & 77.5 & 40 \\
\hline Story-telling & 65 & 55 \\
\hline
\end{tabular}

\subsection{Discussion}

Findings relating to questions on the time teachers devote in the classroom both to the teaching of spoken English and to the practice of speaking activities indicate significant differences between the groups. In both cases, the EOI group devotes more time here and therefore it seems that these teachers in general attach more relevance to the speaking skill. The SE teachers in the survey have been in service on average for more than twenty years while most EOI teachers have taught for between one to five years and hence, they are younger and less experienced. However, this lack of experience does not affect their teaching of spoken language; on the contrary, more experienced SE teachers devote less 
time to it whereas EOI teachers acknowledge taking more than thirty minutes for teaching this skill. Thus, the length of time the participants have been teaching does not correlate with a higher use of speaking in the classroom and we can therefore answer our first question by stating that EOI teachers devote more time both to the teaching of spoken English and to the practice of speaking activities. This may indicate a higher interest in developing their students' communicative competence, as defined by Hymes $(1967,1972)$, that is, the ability to convey and interpret messages as well as the negotiation of meaning. It is the performance of students in the process of communication that allows them to improve the speaking skill. In keeping with Cummins' $(1979,1980)$ observations, it can be said that in our survey EOI teachers focus on basic interpersonal communicative skills, in other words, on context-embedded situations, while SE teachers report devoting less time to the practice of speaking in this sense.

Our second research question focused on which group of teachers pays more attention to pronunciation, accuracy, fluency, interaction with their peers or non-native speakers, and interaction with native speakers in the assessment of speaking. Findings indicate that pronunciation plays a lesser role in the assessment of language proficiency for SE teachers, notwithstanding that the sound system is clearly an essential element in learning to speak in a L2. Also, pronunciation tends to be a difficult issue for students according to Vez et al. (2002), in which pronunciation and grammar proved to be more difficult than fluency. Apparently, then, EOI teachers are more conscious of the importance of sound structure. We know that pronunciation affects all levels of language production and perception, such as reading aloud and it has even been shown to affect learners' identity (Walker, 2010), and inasmuch as it can modify the attitude of learners towards the L2, the sound system of a language is an aspect of great significance in the learning process. For this reason, it is essential to integrate pronunciation in the classroom. Students must be familiar with phonemic distinctions and ongoing assessment here constitutes a helpful tool in the evaluation of the process. Production and perception-based pronunciation tests in the assessment of speaking proficiency are a basic tool. Pronunciation is closely related to interaction and for this reason, interactive tasks should be practised and assessed, considering both interaction with native and non-native speakers.

Findings relating to the questions on interaction with native speakers indicate that although neither group regards this issue as especially relevant, a significant statistical difference is observed between them and for EOI teachers it is definitely seen as a much more important fact. Despite this, neither EOI nor SE teachers attach much relevance to it. The scant importance given to the assessment of interaction with native speakers does not promote instrumental motivation, which is an important learner-based factor in the acquisition of a foreign language. If students were made more fully aware of the possibilities of communication with native speakers of the language through the use of authentic material in the classroom, or reminded more frequently of the possibilities here, this might well enhance their motivation.

Following Brumfit (1984), we can observe that accuracy relates to appropriacy and fluency to what a native speaker produces in speaking, and that both complexity and accuracy occur in the construct of fluency (Bygate, 2009); moreover fluency does not simply indicate the ability to link elements but also the ability to use language in a natural way (cf. Hedge (1993)). In the teaching of English both of these aspects must be tackled, and they are com- 
plementary. Moreover, in the communicative teaching approach, both accuracy and fluency are considered to underpin communicative techniques. Attention to language and language for communication coexist yet the assessment of accuracy is not seen as particularly important by the SE teachers in our survey. Indeed, a significant statistical difference ( $p$-value $=0.007$ ) is observed here in favour of the EOI group. Fluency also seems to be slightly more relevant for EOI teachers. However, both groups appear to be unaware that high levels of fluency do not exist in the absence of accuracy. This is crucial: if students are assessed with authentic tasks working in real time, their accuracy will influence the fluency exhibited, but if authentic tasks are not used less progress will be observed in the students' fluency.

Finally, our third research question asked which group of teachers made greater use of controlled speaking activities and which preferred less controlled activities. As noted above, SE teachers report the use of more controlled activities while EOI teachers prefer less controlled ones involving greater interaction and a more active participation of the students, such as discussion, problem-solving activities, simulations and role-play. The most frequent of the less-controlled speaking activities within the EOI group include role-plays, discussions/debates and simulations. The data show that EOI teachers base speaking activities on a variety of social situations, these activities improve critical thinking, help students to make decisions and train them in communicative skills such as expressing agreement/ disagreement and the paraphrasing of ideas. Finally, simulations foster self-confidence and as Harmer (1984) notes, this improves motivation. The activities chosen by SE teachers seem to be less interactive, implying a higher degree of control on the part of the teacher. The most salient difference between the two groups seems to be that EOI students benefit more from interactive activities and have the chance to practise more real-life situations, such as role-plays and simulations. EOI teachers, then, focus their attention on communication activities which promote interaction.

\section{Conclusion}

Teaching speaking constitutes a central issue in second language learning because it contributes to success in the acquisition of the second language. Teachers play an essential role in the acquisition of this skill in that they are in charge of promoting meaningful communication in the classroom. In this study, important differences have been observed between two groups of teachers. Although SE teachers are more experienced, they report devoting less time to the teaching of speaking while EOI teachers appear to be more engaged in the teaching of this skill. Exposure to input is a key factor in learning to speak and we might then conclude that SE teachers should devote more time in the classroom to the practice of oral skills. If students do not receive sufficient exposure to input, their speaking will not improve adequately. Lack of exposure to the second language not only leads to poor output but in the long run it can also lead to a lack of motivation

EOI professionals devote more time both to teaching activities and to the teaching of speaking. In terms of assessment, the EOI group puts more emphasis on accuracy and although both groups undervalue the assessment of interaction with native speakers, for EOI teachers it is seen to be a more relevant issue. In the use of speaking activities, the EOI group uses less-controlled speaking activities more and they promote interaction, while SE teachers opt 
for more controlled speaking tasks. Even in the use of controlled tasks EOI teachers prefer presentations, while SE teachers prefer activities such as "spot the difference", or "describe and draw" in which students follow guided instructions. The activities used by EOI teachers, then, seem to promote learners' autonomy more, a key point both in the CEFRL and in the new European Credit Transfer System. EOI teachers pay more attention to teaching sound structure, however, neither group seems to show much interest in promoting interaction with native speakers. The EOI teachers do, however, show more interest in assessing this issue. Despite this, foreign language should in fact have as one of its primary aims the communication with native speakers, not least because students will be more motivated if they realize how useful the foreign language is in cross-cultural communication. Hence, more attention should be paid by both groups to improve students' motivation to speak in the L2. On the other hand, accuracy is considered an important element to be assessed by EOI teachers, but not by the SE group. Besides, EOI teachers appear to promote learners' autonomy by practising less-controlled speaking activities which aim at using not only given linguistic patterns but also new vocabulary and formulaic expressions that can improve fluency

For all these reasons, more attention seems to be paid by EOI teachers to the teaching of speaking. More attention should be paid by both EOI and SE teachers to the assessment of interaction with native speakers, which might help to improve students' motivation to speak another language. SE teachers should also devote more time to the practice of this skill. Accuracy should also be assessed by means of specific tasks, as should fluency. Learners' autonomy should be promoted by SE teachers by using less-controlled activities on a regular basis. However, we cannot forget that SE teachers are often constrained by the length of the secondary education syllabus. The development of speaking, which is a political as well as an educational concern, could be improved if attention is paid to the issues discussed above.

With the findings from this exploratory study, we are in a position to replicate the study in other areas of the country. However, it should be borne in mind that the present study is limited to the north-western region of Spain and that teachers from only twelve high schools and two schools of languages participated. Suggestions for further research include the possibility of eliciting data from interviews with the teachers from all over the country and a complementary study looking at whether the different perspectives of both institutions in the teaching of this skill have an effect on the students' proficiency level. The current concern for the state of language learning demands more research and we are just beginning to explore a field of investigation that can add immensely to the improvement of second language teaching in these educational contexts.

\section{REFERENCES}

Argibay, P. (2008). The teaching of spoken English. Unpublished manuscript. Vigo: University of Vigo.

Boxer, D. and Cohen, A. (eds.) (2004). Studying Speaking to Inform Second Language Learning. Clevedon: Multilingual Matters.

Brown, H.D. (1994). Teaching by principles: An interactive approach to language pedagogy. Englewood Cliffs, NJ: Prentice Hall Regents. 
Brown, G. and Yule, G. (1983). Teaching the spoken language. Cambridge: Cambridge University Press.

Brumfit, C. (1984). Communicative Methodology in Language Teaching: the roles of fluency and accuracy. Cambridge: Cambridge University Press.

Bygate, M. (1987). Speaking. Oxford: Oxford University Press.

Bygate, M. (2000). "Tasks in language pedagogy", in Language Teaching Research 4,3:185192.

Bygate, M. M., Skehan, P. and Swain, M. (eds.) (2001). Researching Pedagogic Tasks: Second Language Learning, Teaching and Testing. Harlow: Pearson Education.

Bygate, M. (2009). "Teaching the spoken foreign language", in K. Knapp, and B. Seidlhofer (eds.), Foreign Language and Communication. Berlin: Mouton de Gruyter, Vol 5, 401-438.

Checa Martín, A. (2002)."Communicative language teaching in secondary education. Myths and realities", in A. Bueno González, G. Luque Agullo, F. Molina Navarrete, A.M. Ortega Cebreros, M.L. Pérez Cañado (eds.), Studies in Applied Linguistics and Language Teaching. Jaén: Servicio de Publicaciones de la Universidad de Jaén, 11-30.

Council of Europe (2001). Common European Framework of Reference for Languages: Learning, teaching, assessment. Cambridge: Cambridge University Press. http://www.coe.int/t/dg4/ linguistic/Cadre1_en.asp, accessed 12 July 2013.

Cummins, J. (1979). "Cognitive/academic language proficiency, linguistic interdependence, the optimal age question and some other matters", in Working papers on bilingualism, 19:197-205.

Cummins, J. (1980). "The cross-lingual dimensions of language proficiency: Implications for bilingual education and the optimal age issue", in TESOL Quarterly, 14:175-18.

Ellis, R. (2005). Planning and Task Performance in a Second Language. Amsterdam: John Benjamins.

Eurobarometre survey (2005). Europeans and Languages. Special Eurobarometre 237, Wave 63.4. TNS Opinion and Social. European Commission.

Harmer, J. (1984/1996). The Practice of English Language Teaching. London: Longman.

Hedge, T. (1993)."Key concepts in ELT: Fluency", in ELT Journal, 47: 275-276.

Howatt, A.P.R. (1984). A history of English Language Teaching. Oxford: Oxford University Press.

Hymes, D. (1967). On communicative competence. Unpublished manuscript, University of Pennsylvania.

Hymes, D. (1972). "On communicative competence", in J.B. Pride, J. and Holmes, (eds.), Sociolinguistics. Harmondsworth: Penguin, 269-293.

Lazaraton, A. (2001). "Teaching oral skills", in M. Celce-Murcia and M. Heinle and Heinle, (eds.), Teaching English as a Second or Foreign language. Boston, MA: Heinle and Heinle, 103-116.

Morrow, K. and Johnson, K. (1979). Communicate 1. Harlow: Longman.

Palacios Martínez, I. (1994). La enseñanza del inglés en España a debate. Santiago de Compostela: Servicio de publicaciones de la Universidad de Santiago.

Sanz Muñoz, S. (2011). Aspectos regresivos en la retención de la competencia comunicativa oral en inglés en educación obligatoria. Unpublished PhD. dissertation. Santiago: University of Santiago.

Segalowitz, N. (2003)."Automaticity and second language acquisition", in C. Doughty \& M. Long (eds.). The Handbook of Second Language Acquisition. Oxford: Blackwell Publishers, 382-408. 
Skehan, P. and Foster, P. (2005). "Strategic and on-line planning", in R. Ellis (ed.), Planning and Task Performance in a Second Language. Amsterdam: John Benjamins, 193-216.

Vez, J.M. and Martínez, E. (eds.) (2002). Competencia comunicativa oral en lenguas extranjeras. Investigación sobre logros del alumnado gallego de inglés y francés al finalizar la ESO. Santiago de Compostela: Servicio de publicaciones de la Universidad de Santiago.

Walker, R. (2010). Teaching the pronunciation of English as a Lingua Franca. Oxford: Oxford University Press. 


\section{Appendix 1}

This questionnaire is part of a project that is being carried out at the University of Vigo about the teaching of English in secondary education with the purpose of improving its teaching. The questionnaire is anonymous so please be sincere and clear.

Thank you for participating in the study

1. Sex: Male $\square$ Female

2. Age:

3. What level do you teach?

Primary:

Secondary:

First cycle

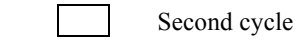

$\square$ Final year

School of Languages:

$1^{\circ}$
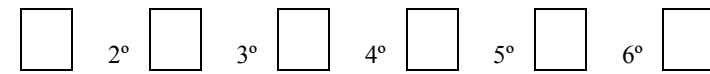

4. How long have you been teaching English?

\section{How long do your classes last?}

50 '

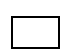

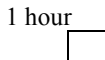

1 hour 30'
2 hours

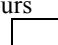

6. How long do you devote to the teaching of English in the classroom?<smiles>[GeH2]C1CCC1</smiles>
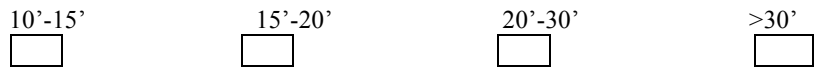

7. How long do your students practise oral activities in the classroom?
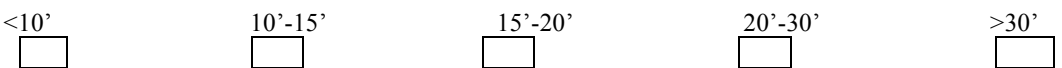

8. When you do speaking activities, what do you assess? (You can tick more than one)

$\begin{array}{ll}\text { Pronunciation } & \begin{array}{l}\text { Interaction with } \\ \text { anyone }\end{array}\end{array}$


9. Select the type of activities that you use in the classroom from the following list.

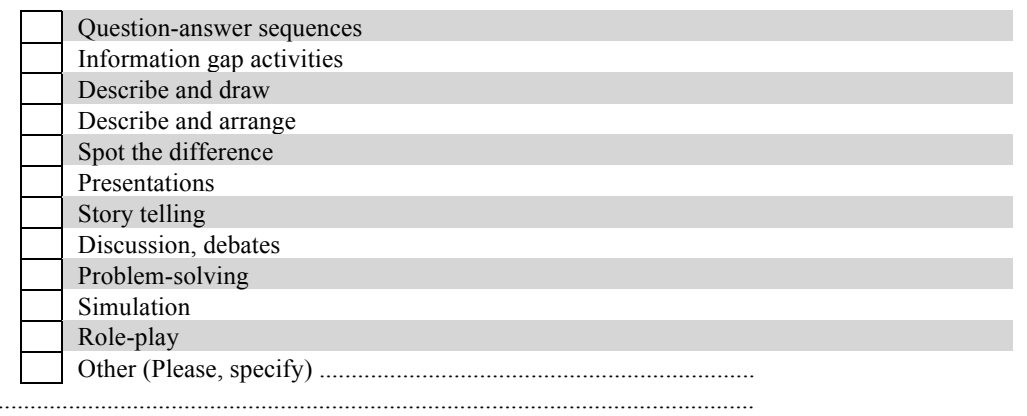

10. How often do you use the activities that you selected in the previous question? (indicate 1-5, where 1 sometimes, 3 often, 4 very often and 5 always).

\begin{tabular}{|c|c|}
\hline Question-answer sequences & $\begin{array}{lllll}1 & 2 & 3 & 4 & 5\end{array}$ \\
\hline Information gap activities & $\begin{array}{lllll}1 & 2 & 3 & 4 & 5 \\
\end{array}$ \\
\hline Describe and draw & $\begin{array}{lllll}1 & 2 & 3 & 4 & 5\end{array}$ \\
\hline Describe and arrange & $\begin{array}{lllll}1 & 2 & 3 & 4 & 5\end{array}$ \\
\hline Spot the difference & $\begin{array}{lllll}1 & 2 & 3 & 4 & 5 \\
\end{array}$ \\
\hline Presentations & $\begin{array}{lllll}1 & 2 & 3 & 4 & 5 \\
\end{array}$ \\
\hline Story telling & 1223345 \\
\hline Discussion, debates & $\begin{array}{lllll}1 & 2 & 3 & 4 & 5 \\
\end{array}$ \\
\hline Problem-solving & 122345 \\
\hline Simulation & $\begin{array}{lllll}1 & 2 & 3 & 4 & 5\end{array}$ \\
\hline Role-play & 1223445 \\
\hline Other & $\begin{array}{lllll}1 & 2 & 3 & 4 & 5 \\
1 & 2 & 3 & 4 & 5 \\
1 & 2 & 3 & 4 & 5 \\
1 & 2 & 3 & 4 & 5 \\
1 & 2 & 3 & 4 & 5\end{array}$ \\
\hline
\end{tabular}

